HOOVER (Stewart), Religion in the News: Faith and Journalism in American Public Discourse

Thousand Oaks, (Ca), London, New Delhi, Sage Publications, 1998, 234 p.

Grace Davie

\title{
OpenEdition
}

Journals

Electronic version

URL: http://journals.openedition.org/assr/20567

DOI: 10.4000/assr.20567

ISSN: $1777-5825$

Publisher

Éditions de l'EHESS

Printed version

Date of publication: 1 July 2000

Number of pages: 83-84

ISBN: 2-222-96691-4

ISSN: 0335-5985

Electronic reference

Grace Davie, « HOOVER (Stewart), Religion in the News: Faith and Journalism in American Public

Discourse », Archives de sciences sociales des religions [Online], 110 | avril-juin 2000, document 110-28,

Online since 19 August 2009, connection on 21 September 2020. URL : http://

journals.openedition.org/assr/20567 ; DOI : https://doi.org/10.4000/assr.20567

This text was automatically generated on 21 September 2020.

(C) Archives de sciences sociales des religions 


\section{HOOVER (Stewart), Religion in the News: Faith and Journalism in American Public Discourse}

Thousand Oaks, (Ca), London, New Delhi, Sage Publications, 1998, 234 p.

\section{Grace Davie}

\section{REFERENCES}

HOOVER (Stewart), Religion in the News: Faith and Journalism in American Public Discourse, Thousand Oaks, (Ca), London, New Delhi, Sage Publications, 1998, 234 p.

1 In Religion in the News, S.H. is concerned primarily with the relationship between two major social institutions in American society -religion and the press. The series of questions that this relationship provokes is tackled from several points of view: empirical, historical and theoretical - with a strong emphasis on social and cultural discourse as the crucial framework within which to understand the more detailed material. The central question is articulated at the outset: «Why is it that in the United States, the most religious of the western industrial countries, the coverage of religion by the secular press continues to be so controversial?» (p. 1). The answer reveals layers of complexity not only within religion and the press themselves, but in the intricate relationships between them.

2 At least part of the problem lies in the «received view» of religion in American public life. The notion of secularisation remains pervasive, despite recent challenges from, amongst others, sociologists of religion. The dominance of secularisation in American intellectual (rather than popular) life is a particularly significant point with respect to the national, if not always the local, media. In addition, religion is thought to be a private, «non-empirical», complex and controversial affair - inevitably difficult to handle - quite apart from the constitutional pressures that derive from the First Amendment. 
3 Such a frame of reference is not set in concrete: it must respond to the changing realities of the modern world, one of which is the dominance of religion in the news stories of the later post-war decades. How, then, should the media come to terms with this situation (the «de-privatisation» of religion to use Casanova's term), given the cultural deposits of American history? It is at this point that S.H. offers us a wealth of empirical material as he looks in detail at the world of the working journalist (the supplier) and at responses to the news on the part of (a) a series of religious specialists and (b) the more general reader or viewer. The greater part of the material concerns journalism rather than broadcasting.

4 I found the sections on the working journalist of particular interest, not least the relationships between the religious specialist and the paper/programme as a whole. Is religion 'hard news' or simply a feature item? Is it primarily a local affair? Is it the preserve of specialists, confined to certain contexts, or should it have the 'run of the paper'? It is at this point that S.H.'s analysis began to resonate with European experience, for even the most gifted of religious correspondents in say Britain or France (just as much as in the United States)will have difficulty making an impact if the senior management of the paper/programme choose not to prioritise religion. Indeed one of the most interesting of S.H.'s findings concerning the world of journalism itself is that media personnel in general are indeed some of the least religious in the United States, but this is not true of the religious specialists who manifest not only knowledge but considerable commitment.

5 The question of prioritising was echoed by the 'specialist' audiences of readers, viewers and listeners. Quite simply, the front page of a paper should reflect the religious life of the nation or the community more often than it does. Or to put the same point in a different way, the assumed localism of the audience was sharply challenged by the clergy and leading laity. The subsequent chapter poses the same question with respect to a wider, less well-informed audience. The data confirm the specialist findings: "There are significant segments of the media audience that see religion as an important element of the broad range of news coverage and not as something that can or should be confined to the private sphere of belief alone». (p. 136).

6 S.H.'s close analysis of the complex relationships between American religion culture, the realm of journalistic practice and the sphere of public discourse is a rewarding read. If the media play an important role in articulating "the religious» for the American reader, something needs to be done to make this more effective at the turn of the millennium. The same is undoubtedly true in Europe. 